\title{
11. CONSOLIDATION AND DEFORMATION OF SEDIMENTS AT THE TOE OF THE CENTRAL OREGON ACCRETIONARY PRISM FROM MULTICHANNEL SEISMIC DATA
}

\author{
Guy R. Cochrane, ${ }^{2,3}$ Mary E. MacKay,${ }^{4}$ Greg F. Moore, ${ }^{4}$ and J. Casey Moore ${ }^{2}$
}

\begin{abstract}
Interpretation of data from a 1989 multichannel seismic (MCS) survey of the central Oregon Margin indicates that pore fluids escaping from the accretionary prism follow paths that are largely fracture controlled and fault guided. MCS evidence of this control includes reversed-polarity, fault-plane reflections, $P$-wave-velocity reversals, and upward deflection of gas hydrate reflections where they cross fault traces on some seismic sections. Site 891 was located on the frontal thrust of the accretionary prism. At this site the thrust dips $8^{\circ}$ landward and produces a high-amplitude, reversed-polarity reflection that suggests the thrust may be a conduit for fluids from the décollement. Site 892 is situated on an out-of-sequence thrust within the prism that is known to be hydrogeologically active. The thrust dips $14^{\circ}$ landward. Upward deflection of the gas hydrate reflection is present where it crosses the fault trace.

In Cascadia Basin, west of the Leg 146 Oregon drill sites, velocity measurements increase within all strata in a landward direction, suggesting that diffusive flow is the dominant dewatering process. In the area of the basin nearest the prism, where incipient deformation was observed, proto-thrusts may augment diffusive flow in the section above a proto-décollement. A velocity inversion in the sedimentary section occurs below the proto-décollement. The depth of the proto-décollement may be at the top of an overpressured sedimentary section below a layer with low permeability.
\end{abstract}

\section{INTRODUCTION}

Multi-channel seismic (MCS) data were collected across the central Oregon accretionary prism in preparation for Ocean Drilling Program (ODP) Leg 146 and as part of our continuing research into the processes of lithification of Cascadia Basin sediment as it is incorporated into the accretionary prism. The MCS survey was designed to define the source zones and migration pathways of fluids being expelled from the accretionary complex and underlying subducting sediments. The MCS data are used to show how structural style and stratigraphy control the location and dimensions of the patterns of fluid venting observed on the seafloor (Kulm et al., 1986).

Here we present some of the processed MCS data from our survey of the margin that was used to locate drill sites off Oregon (Profiles 5 and 9; Fig. 1). For a complete discussion of the structure of the region based on analysis of the entire MCS data set, see MacKay et al. (1992). Cochrane et al. (in press) discuss the velocity analysis, polarity reversals, and fluid migration in the southern area.

\section{DATA ACQUISITION AND PROCESSING}

Over $2000 \mathrm{~km}$ of MCS data were collected from the central Oregon Margin during a single cruise of the Digicon Geo Tide (SeptemberOctober 1989; Fig. 1). The seismic source consisted of a tuned array of air guns with a combined volume of $75 \mathrm{~L}$. Shots were fired at $25-\mathrm{m}$ intervals and recorded by a 144-channel streamer with group spacing of $25 \mathrm{~m}$, yielding 72 -fold common midpoint (CMP) data at a CMP interval of $12.5 \mathrm{~m}$. The maximum streamer offset was $3833 \mathrm{~m}$.

Initial processing was performed at the Hawaii Institute of Geophysics using Phoenix software on an Alliant computer. The prestack processing used to produce the time sections shown in Figures 2 and 3 (back-pocket foldout) included $t^{2}$ gain, spiking deconvolution,

'Westbrook, G.K., Carson, B., Musgrave, R.J., et al., 1994. Proc, ODP, Init. Repts., 146 (Pt. 1): College Station. TX (Ocean Drilling Program).

${ }^{2}$ Earth Sciences, University of California at Santa Cruz, Santa Cruz, CA 95064 , U.S.A.

United States Geological Survey, MS-999, 345 Middlefield Road, Menlo Park, CA 94025, U.S.A.

${ }^{4}$ School of Ocean and Earth Sciences and Techonology (SOEST), University of Hawaii, Honolulu, HI 96822, U.S.A. normal move-out correction, stretch mute, and near-trace mute for multiple attenuation. The velocity analyses for normal moveout corrections of the data were performed using the semblance method (Taner and Koehler, 1969). After stacking, the data were time-variant filtered and migrated using a finite-difference algorithm.

Line 9 data were reprocessed because coherent high-angle noise, the result of side reflections from a nearby submarine canyon and the migration process, obscured features of interest below the first ridge. Line 9 data were prestack FK filtered after normal move-out correction to remove coherent noise from the CMP gathers. The data were then stacked, FK migrated, and FK filtered again to remove steeply dipping noise produced by migration (Fig. 3, in back-pocket foldout). The post-migration FK filtering was windowed so that only areas in which steeply dipping noise was present were filtered.

Depth sections were produced at the U.S. Geological Survey, Branch of Pacific Marine Geology, using DISCO software running on a VAX computer (Figs. 4-6, in back-pocket foldout). The seismic velocities used for the conversion to depth were derived from the MCS stacking velocities and ocean-bottom seismometer (OBS) refraction velocities. The MCS stacking velocity values were converted to interval velocity values using the Dix (1955) equation. This conversion was used only on the basin data and on data from strike lines in the prism where reflections are from near-horizontal stratigraphic and structural surfaces.

\section{DIFFUSIVE DEWATERING IN CASCADIA BASIN}

The stratigraphy of the eastern Cascadia Basin was determined by Kulm et al. (1973) on Deep Sea Drilling Project (DSDP) Leg 18. DSDP Site 174 penetrated $879 \mathrm{~m}$ of sediment. The hole failed to reach acoustic basement, which was at an estimated depth of $911 \mathrm{~m}$. The oldest sedimentary unit (Unit 2; Fig. 7) is a late Miocene to early Pliocene, calcareous, silty clay. This unit grades upward into Pliocene and Pleistocene silt turbidites, which were interpreted to be abyssal-plain facies. An unconformable contact separates these silt turbidites from the overlying sand-dominated section (Unit 1). The overlying section is composed of middle to late Pleistocene, Astoria Fan turbidites.

At DSDP Site 174, Unit 1 had a thickness of $284 \mathrm{~m}$. The remaining section $(627 \mathrm{~m})$ was composed of the older Unit 2 . Interpretation of the depth sections for MCS lines 5 and 9 (Figs. 4-6) indicates a 


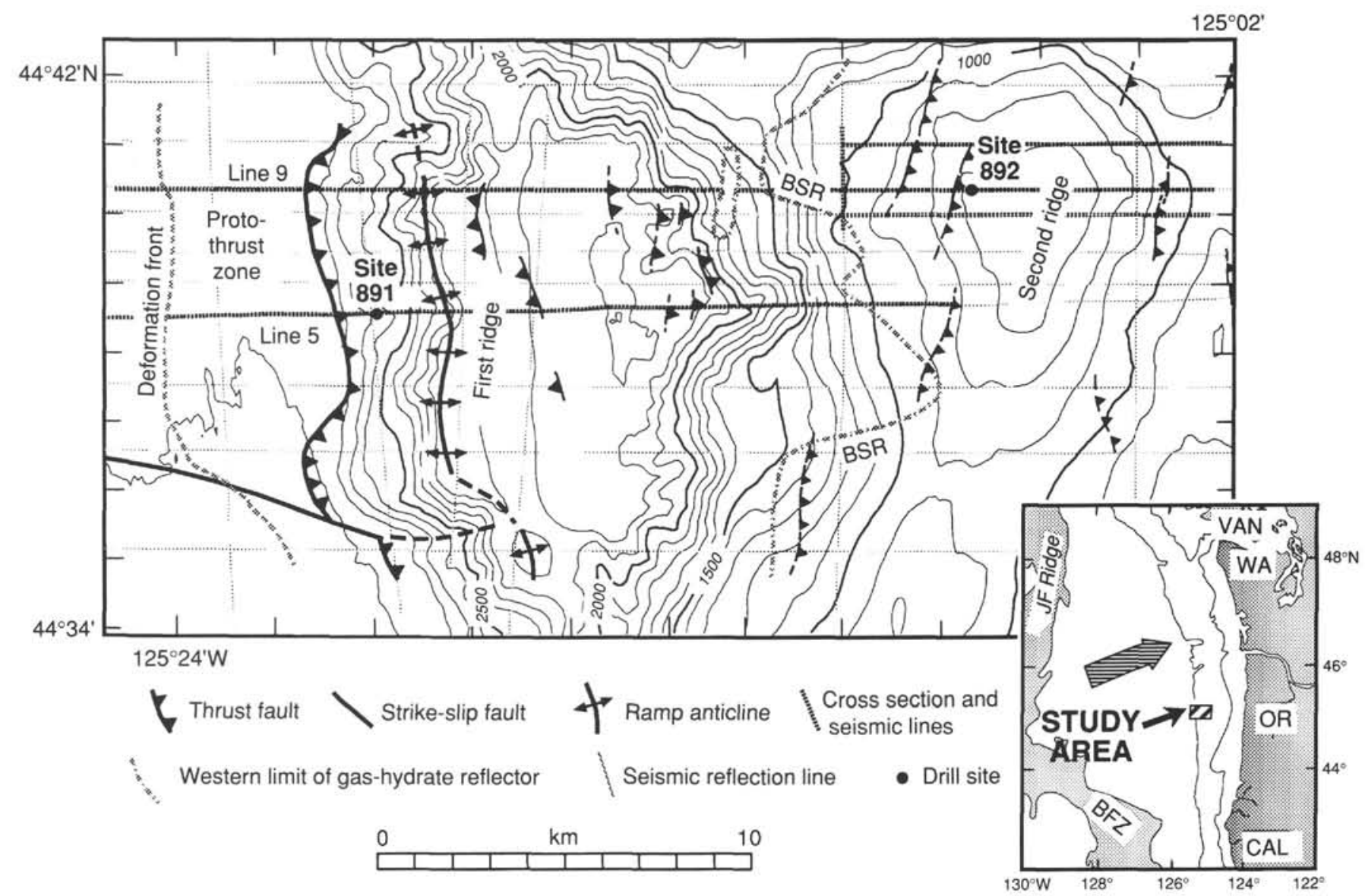

Figure 1. Map showing track lines of the 1989 MCS survey of the Oregon Margin. Only the southern portion of the 1989 MCS survey area is shown. Contours of bathymetry from Sea Beam data are in meters. BSR = bottom-simulating (gas-hydrate) reflector, BFZ = Blanco Fracture Zone, JF Ridge = Juan de Fuca Ridge, $\mathrm{WA}=$ Washington, $\mathrm{OR}=$ Oregon, $\mathrm{CAL}=$ California, and $\mathrm{VAN}=$ Vancouver, $\mathrm{B} . \mathrm{C}$.

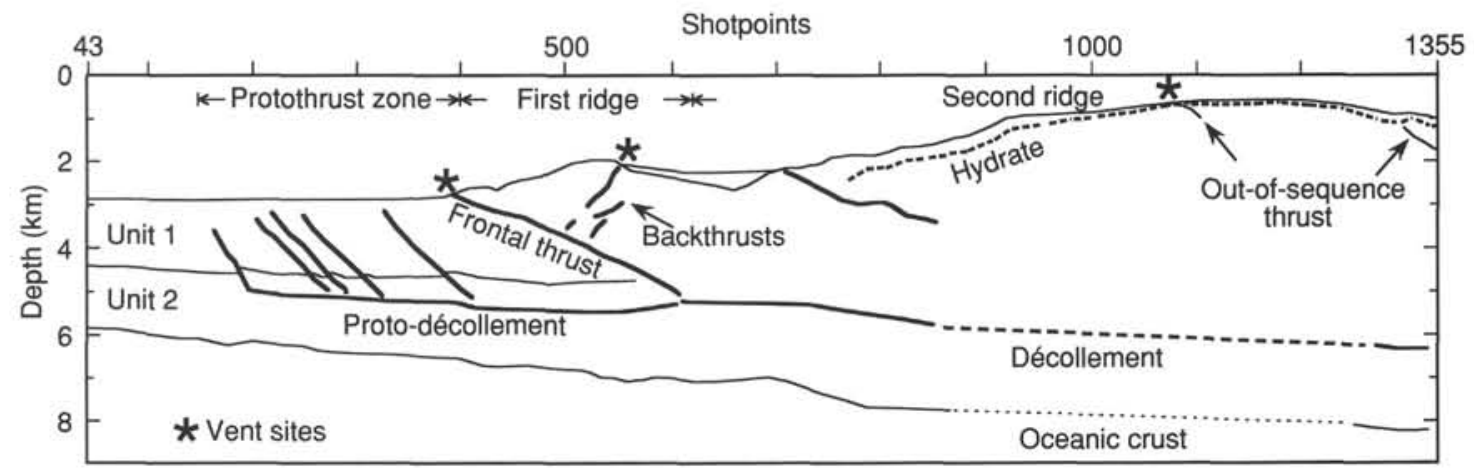

Figure 7. Line drawing interpretation of line 9 depth sections.

thickness of approximately $1800 \mathrm{~m}$ for both units at the base of the slope (Shotpoint 350, Fig. 5). This geometry implies significant landward thickening of both units.

The oceanic crust is well imaged beneath the basin. In the depth sections produced for this paper, the dip of the oceanic crust is approximately $4^{\circ}$ (Figs. 4-6). An earlier OBS experiment (Cochrane et al., 1988) was unable to resolve the dip of the oceanic crust in this area because that experiment was designed for the resolution of velocity values in the sedimentary section. The 1989 MCS survey included a deep crustal line just north of the area shown in Figure 1. The estimated dip of oceanic crust along that line was $5^{\circ}$ (Trehu et al., 1992). This estimate is probably the most accurate in part because the deep crustal line is more nearly parallel to the direction of convergence (N69 ${ }^{\circ}$; DeMets et al., 1990).

Velocity values in the basin west of the proto-thrust zone increase with depth and distance landward (Figs. 7-8). In the proto-thrust zone, velocities above the proto-décollement increase landward, but a vertical and horizontal velocity reversal occurs in the entire section below 


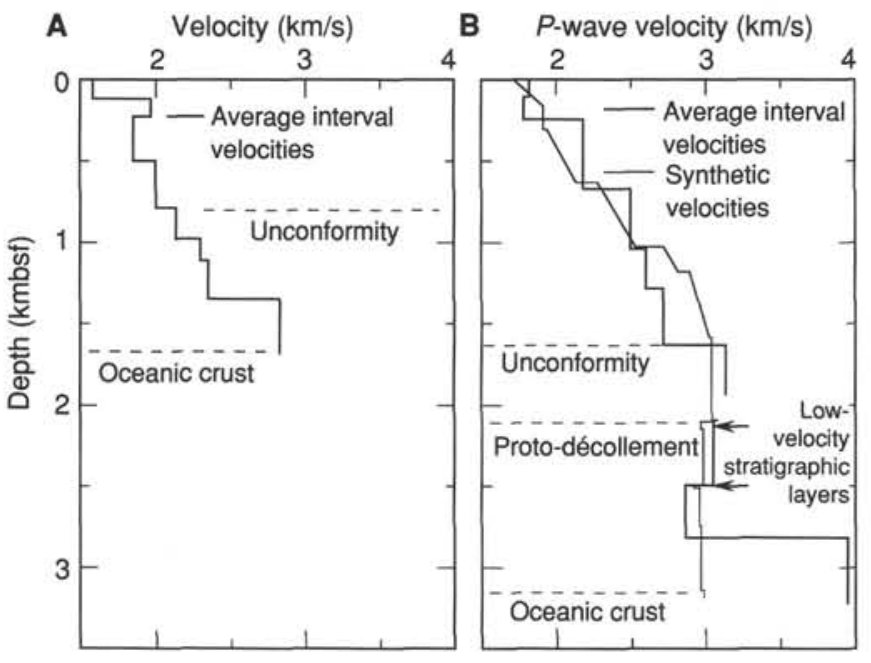

Figure 8 . Vertical $P$-wave velocity profiles derived from MCS velocity data showing landward increase in thickness and velocity of sediment in Cascadia Basin. The stacking velocity profiles are averaged from 6 CMPs where crossings occur between strike and dip lines. A. Interval velocities from the undeformed Cascadia Basin approximately $30 \mathrm{~km}$ seaward of the proto-thrust zone. B. Interval velocities from the proto-thrust zone. The synthetic data profile was derived by modeling the amplitude and phase changes in a stacked CMP trace from the same area (using AIMS software). Arrows indicate the depth of stratigraphic layers observed in the MCS data that produce reverse polarity reflections and were modeled as low-velocity intervals. Figure modified from Cochrane et al. (in press).

the proto-décollement (Fig. 8B). There is a lower velocity in the section below the proto-décollement than the velocity in the section above, and the velocity in the section below the proto-décollement increases seaward.

\section{FOCUSED FLOW IN THE ACCRETIONARY PRISM}

The deformation of Cascadia Basin sediment begins in the protothrust zone that extends $5-6 \mathrm{~km}$ seaward of the base of the slope (Shotpoints 180-380; Fig. 3). Proto-thrusts in this area sole out into a proto-décollement at a depth of $5.0 \mathrm{~km}$ below sea level (Shotpoint 400; Figs. 3 and 7). The proto-décollement appears to have propagated out along a stratigraphic layer that is deeper in the section than the unconformity between Units 1 and 2 of Kulm et al. (1973).

The proto-décollement layer is too thin to determine the $P$-wave interval velocity from the stacking velocity using the Dix (1955) method. Synthetic seismogram modeling was used by Cochrane et al. (in press) to show that the layer is a low-velocity interval (Fig. 8B). The synthetic seismogram model (Fig. 8B) shows an additional lowvelocity interval below the proto-décollement that also corresponds to a single stratigraphic layer.

Velocities in the foot wall of the frontal thrust are higher than velocities of coeval sediment in the basin (Cochrane et al., in press). In the hanging wall they are lower than at a comparable depth in the proto-thrust zone, possibly because of microfracturing from folding (Lewis, 1991).

In the area of the margin drilled on Leg 146, an east-dipping frontal thrust steps up from the décollement $(5.1 \mathrm{~km}$ below sea level at Shotpoint 625; Fig. 3) and intersects the seafloor at Shotpoint 380 (Fig. 3). Thrusting has formed a seaward-verging ramp anticline called the first ridge (Fig. 7). The first ridge is cut by several minor west-dipping backthrusts best imaged in the FK-filtered data (Fig. 6).

High-amplitude, reversed-polarity reflections (with respect to the seafloor reflection) are associated with both the frontal thrust and backthrusts (Moore et al., 1991). Reversed-polarity reflections may result from the underthrusting of relatively lower density material, but they are also consistent with an increase in porosity within the fault zone. An increase in porosity would decrease the acoustic impedance of the rock in the fault zone by reducing the velocity and by reducing the density. Fluid vents are associated with the frontal thrust and backthrust in this area, as well as along sandy horizons where headless submarine canyons have cut the anticlinal ridge (Moore et al., 1990; Orange and Breen, 1992). Using the submersible Alvin, Moore et al. (1990) observed vents where the frontal thrust intersects the seafloor in the area of line 5. Line 9, on the other hand, lacks these vents but has vents where the backthrust intersects an erosional canyon to the north of the first ridge. Finally, no backthrust is present in the first ridge from line 5 south. Moore et al. (1990) proposed that the frontal thrust is locked, either because of dewatering or because of a local decrease in wedge taper associated with the development of the headless canyon to the north. Locking of the frontal thrust lead to failure along the backthrust. The backthrust subsequently captured fluid flow from the frontal thrust and porous strata because faultparallel permeability is greater than permeability across the fault.

The folding and uplifting of sediment ponded behind the first ridge record continued thrusting of the leading thrust sheet. Lewis and Cochrane (1990) proposed that vents on the landward side of the first ridge are generated by flow updip along porous strata in the ponded sediment on the basis of Alvin observations and high resolution deep-tow seismic reflection data. When the fluid reaches the unconformity between the ponded sediment and the underlying folded basin sediments, it is redirected up along the unconformity. The interpretation shown in this paper (Fig. 7) reflects the model of Lewis and Cochrane (1990). The interpretation by Moore et al. (1990) of the seismic data indicates that the volume of ponded sediment is less than the estimate of Lewis and Cochrane (1990) and that the unconformity outcrops landward of the vent sites.

The underthrusting sediments and oceanic crust can be traced beneath the first ridge, but they disappear beneath the second ridge. The subducted sediment is better imaged on line 5 (Figs. 6-7) than on line 9 (Figs. 4-5), probably because on line 9 side reflections are evident from the large headless canyon to the north (Fig. 1). The depth of the décollement and the top of the oceanic crust shown in Figure 7 are based on strong flat-lying reflections best seen on the line 9 FK-filtered depth section (Fig. 6) at 6.5 and $8.3 \mathrm{~km}$ at Shotpoint 1300.

The large size and seismic opacity of the second ridge suggests substantial internal deformation. In fact, the second ridge is underlain by poorly imaged east-dipping thrusts and is cut by several out-ofsequence thrusts associated with fluid vents (Moore et al., 1991).

A prominent gas hydrate reflector (bottom-simulating reflector [BSR]) is present landward from the crest of the second ridge (Figs. 7 and 9). The BSR is deflected upward in the area where it intersects the out-of-sequence thrust on line 9, consistent with fluid flow up the fault plane (see "Site 892" chapter, this volume).

Reliable velocity data for the second ridge were not obtained before drilling took place on Leg 146. The deep crustal imaging line (Trehu et al., 1992) did not cross the second ridge, and OBS deployments were not designed for that purpose. Stacking velocities from the 1989 MCS lines over the second ridge were not useful because of the scarcity of coherent flat-lying reflectors, with the exception of the gas hydrate reflection. A detailed analysis of stacking velocities from the hydrate reflection did not reveal a velocity reversal associated with that reflection. The gas hydrate reflection is a reversed polarity reflection, however, showing that an acoustic impedance reversal is present.

\section{DISCUSSION OF DRILL SITES, OBJECTIVES, AND ASSOCIATED SEISMIC DATA}

The importance of faults in capturing fluids early in the structural evolution of the relatively permeable Cascadia Basin sediments was an unanticipated result of exploration of the area before the 1989 MCS 


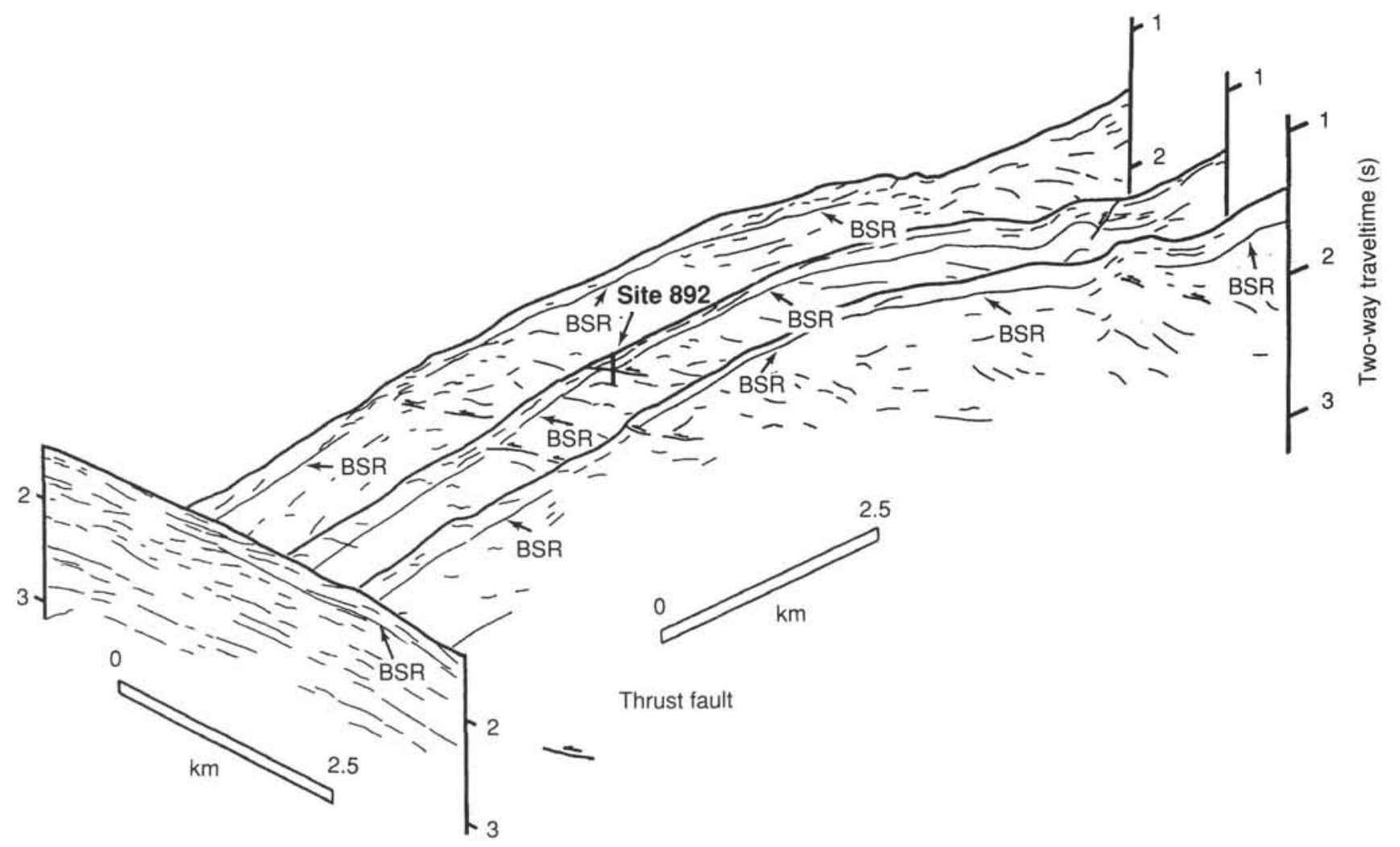

Figure 9. Line drawing of second ridge showing extent of gas-hydrate reflector (BSR), position of out-of-sequence thrusts, and location of Site 892.

survey (Moore et al., 1990). Investigations using Alvin after the acquisition of the MCS data focused on exposed faults that leak fluids. The primary Oregon drilling objective was to carry the study of these fault conduits into the subsurface.

The MCS data show reversed-polarity reflections from the frontal thrust in the seaward-verging area (MacKay et al., 1992). Along line 5 seepage vents were observed where the frontal thrust intersects the seafloor during Alvin dives. Vents were also observed along erosional exposures of sandy strata. Similarly located vents were not observed along line 9. However, vents were observed along the intersection of the backthrust (which developed in the first ridge north of line 5) and the seafloor. Site 891 on line 5 (Figs. 10-11) was proposed to test whether the frontal thrust and the associated décollement provide a conduit for deeply sourced fluids.

Site 892 is situated on the hanging wall of an out-of-sequence thrust fault in the second ridge (Figs. 10 and 12). Reversed polarity reflections, an upward deflection of the BSR, and vent communities are associated with this fault (Shotpoint 1092; Fig. 5), suggesting that fault-guided, fracture-controlled fluid flow also occurs here (Moore et al., 1991). An extensive carbonate bioherm has been observed in this area $\left(30,000 \mathrm{~m}^{2}\right.$; Carson et al., 1991) that is composed of clam shells, bacterial mat fragments, and volcanic rock fragments cemented by the precipitation of aragonite from fluids flowing up through fractures in the hanging wall (P. Jeanbourquin, pers. comm., 1992). Site 892 was proposed to sample rock and fluid from the hanging wall and the fault to detect the presence of geologic and chemical evidence of focused flow.

Focused flow has not been observed in the Vancouver area of the Cascadia Margin. The gas hydrate in the Vancouver area is thought to have formed by the extraction of methane from diffuse upwardflowing pore water, based on seismic modeling of MCS and heat-flow data (Hyndman and Davis, 1992). Site 892 was also proposed to study gas hydrate formation in a location where fracture-controlled and

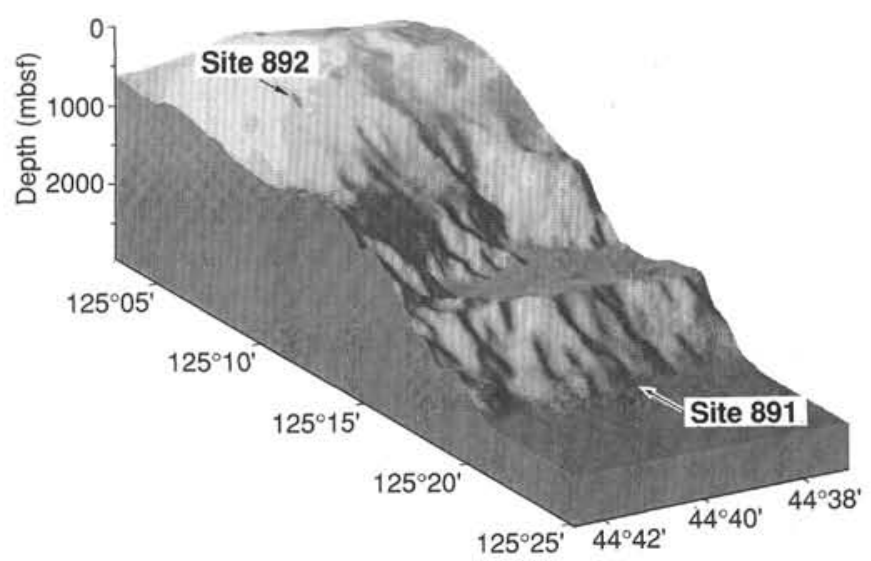

Figure 10. Shaded-relief bathymetry of the southern (seaward-verging) area of the 1989 MCS survey. The first and second anticlinal ridges are shown, although the MCS data extends up onto the shelf. The deepest area shown is Cascadia Basin. Both Leg 146 Oregon drill sites are located in this area. Perspective is from the northwest.

fault-focused flow is known to occur and then to contrast it with results from the Vancouver sites.

\section{ACKNOWLEDGMENTS}

This research was supported by NSF Grants OCE- 8813907 (UCSC), OCE-9116368 (UCSC), and OCE-8821577 (UH). We thank LaVerne Kulm for his thoughtful contributions to this project. Mike Fisher, Holly Ryan, and an anonymous reviewer provided helpful critical reviews. 


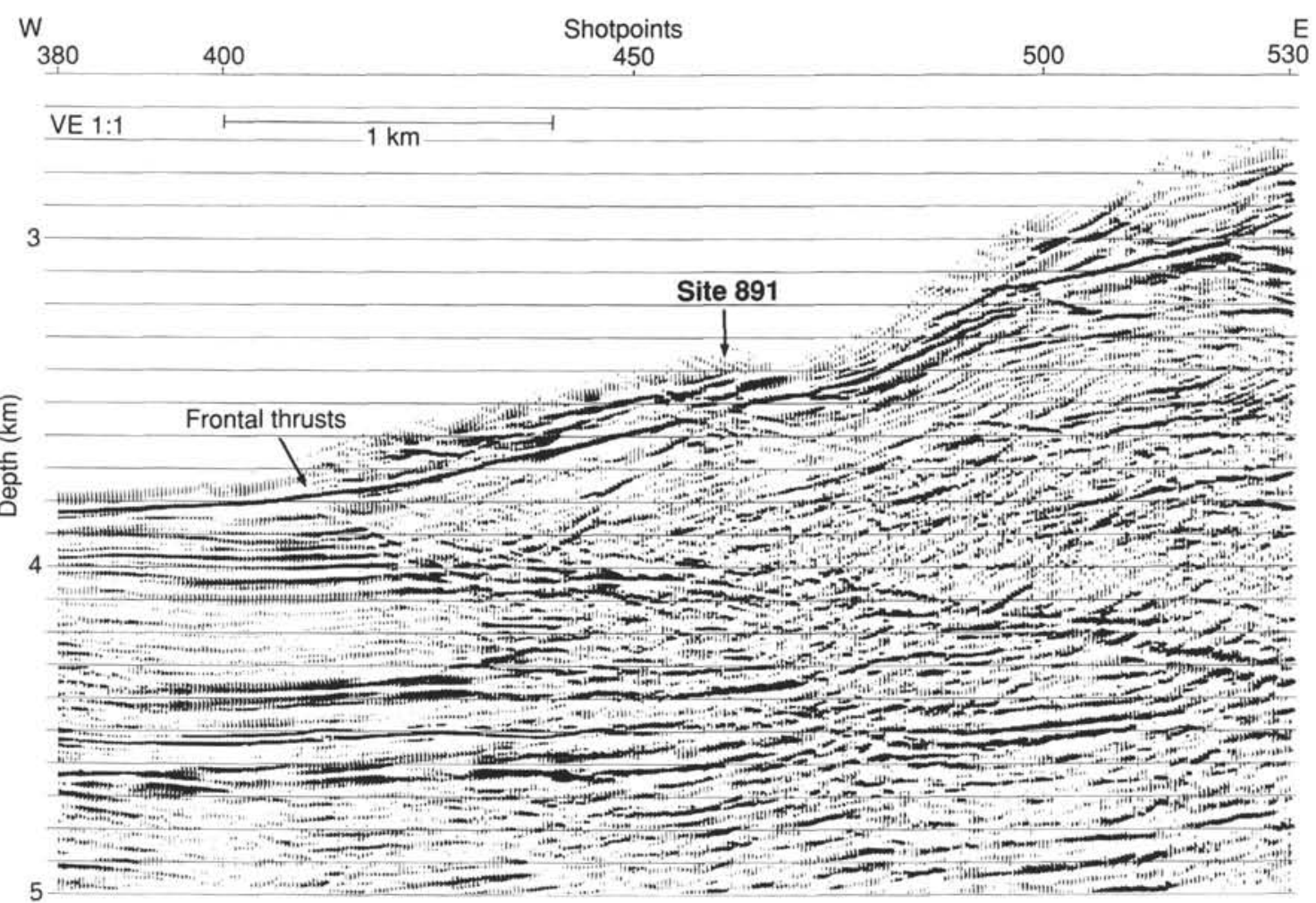

Figure 11. Detailed depth section of 1989 MCS data from line 5 in the area of Site 891 . Depths are in kilometers, with no vertical exaggeration. In the area of the drill site, the frontal thrust dips at approximately $8^{\circ}$ landward.

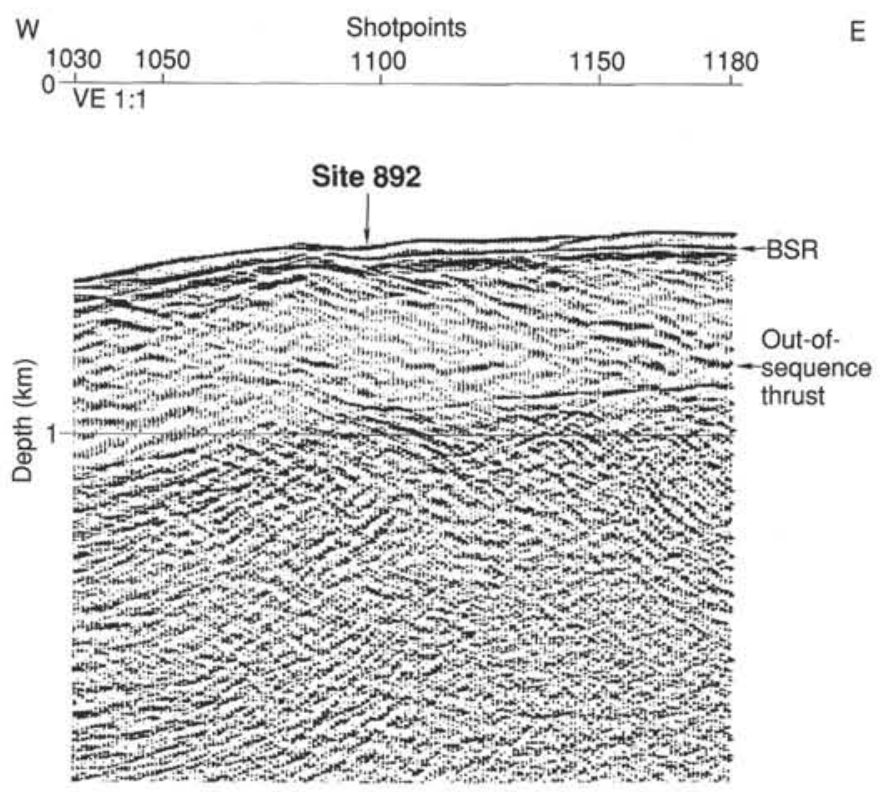

Figure 12. Detailed depth section of 1989 MCS data from line 9 in the area of Site 892. Depths are in kilometers, with no vertical exaggeration. The out-ofsequence thrust dips approximately $14^{\circ}$ landward beneath the drill site. The gas-hydrate BSR is deflected upward where it crosses the fault. 


\section{REFERENCES*}

Carson, B., Holmes, M.L., Umstattd, K., Strasser, J.C., and Johnson, H.P., 1991. Fluid expulsion from the Cascadia accretionary prism: evidence from porosity distribution, direct measurements, and GLORIA imagery. Philos. Trans. R. Soc. London A, 335:331-340.

Cochrane, G.R., Lewis, B.T.R., and McClain, K.J., 1988. Structure and subduction processes along the Oregon-Washington Margin. Pure Appl. Geophys., 128:767-800.

Cochrane, G.R., Moore, J.C., MacKay, M.E., and Moore, G.F., in press. Velocity-porosity model of the Oregon accretionary prism from seismic reflection and refraction data. J. Geophys. Res.

Demets, C., Gordon, R.G., Argus, D.F., and Stein, S., 1990. Current plate motions. Geophys. J. Int., 101:425-478.

Dix, C.H., 1955. Seismic velocities from surface measurements. Geophysics, 20:68-86.

Hyndman, R.D., and Davis, E.E., 1992. A mechanism for the formation of methane hydrate and seafloor bottom simulating reflectors by vertical fluid expulsion. J. Geophys. Res., 97:7025-7041.

Kulm, L.D., Prince, R.A., Snavely, P.D., Jr., 1973. Site survey of the Northern Oregon Continental Margin and Astoria Fan. In Kulm L.D., von Huene R., et al., Init. Repts. DSDP, 18: Washington (U.S. Govt. Printing Office), 979-987.

Kulm, L.D., Suess, E., Moore, J.C., Carson, B., Lewis, B.T., Ritger, S.D., Kadko, D.C., Thornburg, T.M., Embley, R.W., Rugh, W.D., Massoth, G.J., Langseth, M.G., Cochrane, G.R., and Scamman, R.L., 1986. Oregon subduction zone: venting, fauna, and carbonates. Science, 231:561-566.

Lewis, B.T.R., 1991. Changes in $\mathrm{P}$ and $\mathrm{S}$ velocities caused by subduction related sediment accretion off Washington/Oregon. In Kloven, J., and Stoll, R. (Eds.), Shear Waves in Marine Sediments: Dordrecht (Kluwer Academic), 379-386.
Lewis, B.T.R., and Cochrane, G.R., 1990. Relationship between the location of chemosynthetic benthic communities and geologic structure on the Cascadia subduction zone. J. Geophys. Res., 95:8783-8793.

MacKay, M.E., Moore, G.F., Cochrane, G.R., Moore, J.C., and Kulm, L.D., 1992. Landward vergence and oblique structural trends in the Oregon Margin accretionary prism: implications and effect on fluid flow. Earth Planet. Sci. Lett., 109:477-491.

Moore, J.C., Brown, K.M., Horath, F., Cochrane, G., MacKay, M., Moore, G., 1991. Plumbing accretionary prisms: effects of permeability variations. Philos. Trans. R. Soc. London A, 335:275-288.

Moore, J.C., Orange, D., and Kulm, L.D., 1990. Interrelationship of fluid venting and structural evolution: Alvin observations from the frontal accretionary prism. J. Geophys. Res., 95:8795-8808.

Orange, D.L, Breen, N.A., 1992. The effects of fluid escape on accretionary wedges, II. Seepage force, slope failure, headless submarine canyons, and vents. J. Geophys. Res., 97:9277-9295.

Taner, M.T., and Koehler, F., 1969. Velocity spectra-digital derivation and applications of velocity functions. Geophysics, 34:859-881.

Trehu, A., Nabelek, J., Azevedo, S., Brocher, T., Mooney, W., Luetgert, J., Asudah, I., Clowes, R., Nakamura, Y., Smithson, S., and Miller, K., 1992. A crustal cross-section across the Cascadia Subduction Zone in Central Oregon. Eos, 73:391.

\footnotetext{
"Abbreviations for names of organizations and publication titles in ODP reference lists follow the style given in Chemical Abstracts Service Source Index (published by American Chemical Society).
}

\section{Ms 146IR-003}

